特発性栓球減少性紫斑病の本態に関する

臨床的並びに実験的研究

\author{
第 1 編 \\ 特発性栓球減少性紫斑病患者血清の健康人 \\ 骨髄巨核球機能に及ぼす影響 \\ 岡山大学医学部平木内科（主任 : 平木 潔教授） \\ 本多正愳
}

[昭和 34 年 3 月 2 日受稿]

内容目次

第 1 章 緒 言

第 2 章 実験材料並びに実験方法

A) 実蛤材料

B）実験方法

C) 観察方法

第 3 章 実験成績

\section{第1章 緒言}

1738年 Werlhof が皮下出血集その出血性素 因を主徽とする所謂 Werlhof 氏病を記载し，1887 年 Denys1) が本症末梢血中の栓球数減少のある事 実を報告して以来，多くの学者が之を追試し，出血 性素因と栓球減少の間に一定の関係のある事が尔ら れて来た. Frank2)(1915) は，之を本態性栓球减少 症と命名し，その栓球減少は，骨髄巨核球の成熟障 碍に依るすのであると報告した，以来本症病因につ き，患者血液乃至体液中の栓球破坮因子の存在を主 張する者もあり，又，Kaznelson(1916) は，本症 が剔脾によつて一時的乃至持続的に栓球增多, 出血 性素因の轻減を来す事実を認めた。一方, 近年 ACTH, Cortison が本症の栓球增多, 出血性素因の 軽減に卓効を示す事実が認められて以来, 免度学的 機枟を本症の栓球減少，出血性素因の発現の成因之 して举けている者も見られる4)_10). 斯くの如く，本 症に於ける栓球減少の成因に関しては諸説あり， Kaznelson(1916) の脾に於ける栓球破壊儿進説を除 き，前記 Frank の説が有力視されている. 而して 栓球を論ずるに当つて，その，母細胞である目核球
A）健康人骨髄培養
B）特発性栓球減少性紫斑病患者骨髄培丵
C）特発性栓球減少性紫斑病患者血清添加 培養

第 4 章 総括並びに考按

第 5 章 結論

を無視する事は出来ない.との点に関してす，多く の研究がなされている、一方，Frank のいう巨核球 成熟障碍を来す因子の奈辺にありやの点に関しては, 患者血液, 脾, その他の臟器内にその因子あると主 張されてはいるが，今日尚定説がない，私は本症の 栓球诚少の成因と目される巨核球機能を障碍する因 子の有然を追求する為, 教室考案の簡易骨髄組織培 灙法(1)(2)13)14）を用いて，健康人骨髄，本症患者骨 蹥を培養して，巨核球産生能の推移を観察する一方， 本症患者血清を趾康人骨䯣に添加培㦈した。その結 果，從来まで推測に過ぎなかつた本症患者血清中に 存在する催栓球减少性因子の骨髓巨核球に対する直 接作用について，新知見を得たので茲に報告し，諸 賢の御批判を仰ぎたいと思う。

\section{第 2 章 実験材料並びに実験方法}
A）实験材料

1）培養用骨䯣組織片の採取

骨髄穿刺針にて㯬康人及び血液像, 出血時間, 凝 固時間, 毛細血管渗透性等の検查により, 診断の確 定した特発性栓球減少性柴玨病患者の胸骨穿刺を行 い, 2 cc ツペルクリン注射筒にて強く骨能内容を 
吸引して得られた骨鹃組織片を、リンゲル氏液で十 分洗い，直ちに実験に用いた。－一方同時に有核細胞

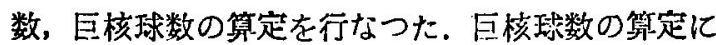
は，白血球用メランジュールに胃髄穿刺液を取り， チユルク氏液にて一定度に稀釈し，フックス・ロー ゼンタール計算盤上にて $1 \mathrm{~mm}^{3}$ 中の数を算出し $た^{15)}$.

2）血清探取

実験当日，早朝空腹時に时静脈より堿菌乾燥した 注射器にて $5 \sim 10 \mathrm{cc}$ 採血し，整時 $37^{\circ} \mathrm{C}$ の睬卵器 内に静置して血清分離の始まるを待ち，約3000回転 15分間遠心沈溉して血清を分噰使用した。

\section{B）実験方法}

実験は，厚ささ $0.9 \mathrm{~mm}$ のスライドグラスを十分 清拭，脱脂，乾熱，滅菌して用いた。

予めスライドグラスの上に市販の張符䀡紙 (10x $20 \mathrm{~mm})$ を, $2.5 \mathrm{~cm}$ の間隔にて 3 枚づつ貼付して 約 $600 \mu$ の土手を作つて置く．その中央に，血清 （患者又は健康人）をツベルクリン注射筒に $1 / 2$ 皮 上注射針を付けたものから 1 滴滴下，直径 $1.5 \mathrm{~cm}$ の円形に硝子棒で拡ける．次いで骨䯣組織片（患者 又は健康人）の $0.5 \mathrm{~mm}^{2}$ 以下の大きさのむのを 1 個置き，その上からビタミン $\mathrm{B}_{12}(1 \mathrm{cc}$ 中 $100 \gamma$ 含 有）注射液を 1 滴滴下した，然る後に，全体をカバ 一グラスで掩い，周囲をパラフィンで封じ，標本を 裹返して $37^{\circ} \mathrm{C}$ の瞬卵器内に入れ静置した。

以上の諸操作は，可及的迅速且つ然菌的に行なわ ねばならぬ.

\section{C） 観察方法}

培美後 $12,24,36$ 時間後標本を取り出し， $37^{\circ} \mathrm{C}$ の 保温箱内にて，顕微鏡を用いて，原組織より遊出し た巨核球の出現個数，及びこの荤動形態を䚁察した。 巨核球の運動形態を，次の如く 3 型に分つ事が出来 る. 即与,
A 型 胞体の軽度変形を認めるもの
B型 隐足形成のあるもの
C 型 蚛手状突起形成を認栓球分噰を示すす の

更に組織増生面皘並びに好中球游走速度をアッべ 氏描画器を用いて描画測定した。

\section{第3 章 実 験成 綡}

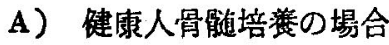

健康人（男子 6 名，女子 1 名）の胸骨”骨随穿制で

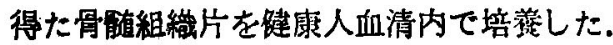

図 I，表 I，(No.1～7）の如く，增生帯に出現 する巨核球数は，培皦12時間後2.2 9.3個，平均 5.3個，同24寺間後 2.0 14.0 個，平均5.3個，同36 時間後3.0 14.0個，平均5.7個であつた. 次いで， その運動形態を見るに四 I，表 I，(No. 1 7) の如 く，培養12時間後 $\mathrm{A}$ 型 9.5 33.3\%，平均 21.9\%， $\mathrm{B}$ 型8.3 23.8\%，平均15.9\%， C 型8.3 23.8\%,

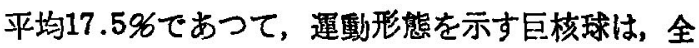
出現巨校球の内平均55.3\%を占めていた。培養24時 間後 A 型14.5 27.7\%，平均 20.7\%，B型5.2 $22.2 \%$, 平均 $18.5 \%, \mathrm{C}$ 型 $0 \sim 21.1 \%$, 平均 $10.8 \%$

因 I硉康人骨䯣培養

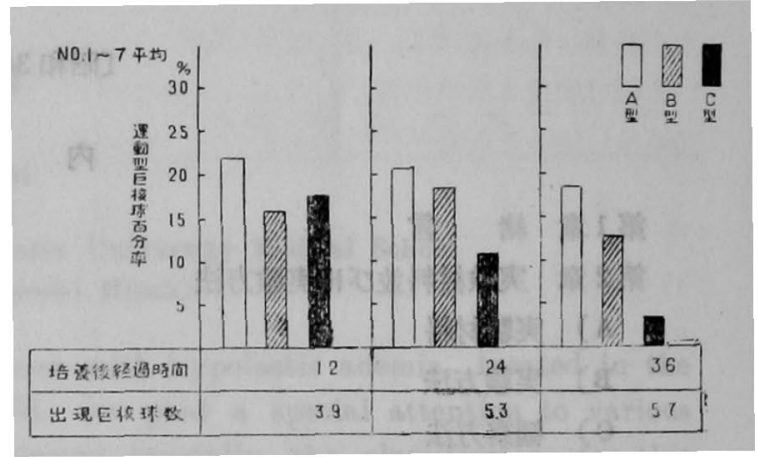

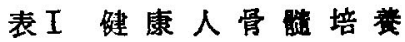
No. 1 西, $38 \mathrm{Y} \cdot \hat{\sigma}$ 巨核球数 $60 / \mathrm{mm}^{3}$

\begin{tabular}{|c|c|c|c|c|c|c|}
\hline \multicolumn{4}{|c|}{ 培美後経過時間 } & 12 & 24 & 36 \\
\hline \multicolumn{4}{|c|}{ 出現巨核球 数 } & 2.4 & 3.2 & 4.0 \\
\hline \multirow{4}{*}{ 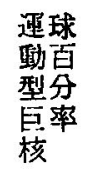 } & A & 型 & \%6 & 33.3 & 18.8 & 10.0 \\
\hline & B & 型 & 96 & 8.3 & 12.1 & 10.0 \\
\hline & C & 型 & $\not 6$ & 8.3 & 0 & 0 \\
\hline & 合 & 計 & 96 & 50.0 & 31.3 & 20.0 \\
\hline \multirow{2}{*}{\multicolumn{4}{|c|}{$\begin{array}{c}\text { 比 較 成 長 価 } \\
\text { 好中球遊走速度 } \mu / \mathrm{min}\end{array}$}} & 13.66 & 24.90 & 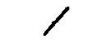 \\
\hline & & & & I & I & I \\
\hline
\end{tabular}

No. 2 岡O $27 \mathrm{Y}:$ 合 * $42 / \mathrm{mm}^{3}$

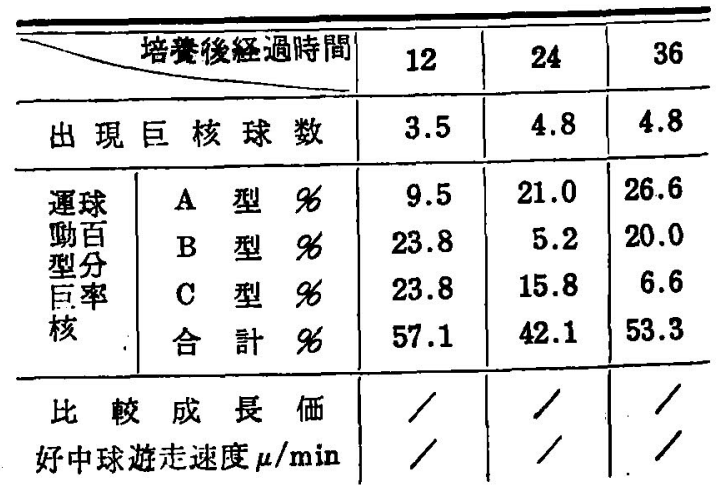

*: 巨核球数 
No. 3 山O 30Y : $\delta$

\begin{tabular}{|c|c|c|c|c|c|}
\hline \multicolumn{3}{|c|}{ 一掊婁後経過時間 } & 12 & 24 & 36 \\
\hline \multicolumn{3}{|c|}{ 出現巨核球数 } & 3.0 & 4.0 & 5.0 \\
\hline \multirow{4}{*}{ 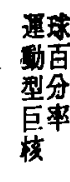 } & A 型 & 96 & 22.2 & 25.0 & 20.0 \\
\hline & B 型 & 96 & 22.2 & 16.6 & 13.3 \\
\hline & C 型 & $\not \%$ & 22.2 & 8.3 & 6.6 \\
\hline & 合 計 & 96 & 66.7 & 50.0 & 40.0 \\
\hline & 成 長 & 価 & 5.01 & 5.45 & $\gamma$ \\
\hline \multicolumn{3}{|c|}{ 好中球遊走速度 $\mu / \mathrm{min}$} & 16.56 & 13.36 & $\ell$ \\
\hline
\end{tabular}

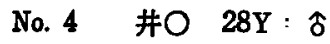

* $72 / \mathrm{mm}^{3}$

\begin{tabular}{|c|c|c|c|c|c|c|}
\hline \multicolumn{4}{|c|}{ 培養後経過時間 } & 12 & 24 & 36 \\
\hline \multicolumn{4}{|c|}{ 出現巨核 球 数 } & 2.2 & 4.5 & 4.5 \\
\hline \multirow{4}{*}{$\begin{array}{l}\text { 運球 } \\
\text { 動百 } \\
\text { 型分 } \\
\text { 核 }\end{array}$} & $\mathbf{A}$ & 型 & 96 & 27.2 & 27.7 & 16.6 \\
\hline & B & 型 & 96 & 18.1 & 22.2 & 11.1 \\
\hline & C & 型 & 96 & 9.1 & 0 & 0 \\
\hline & & 計 & 96 & 54.5 & 50.0 & 27.7 \\
\hline \multirow{2}{*}{\multicolumn{4}{|c|}{$\begin{array}{c}\text { 比 成 长 価 } \\
\text { 好中球遊走速度 } \mu / \mathrm{min}\end{array}$}} & 8.70 & 11.46 & $\gamma$ \\
\hline & & & & 13.04 & 12.73 & I \\
\hline
\end{tabular}

No. 5 平 $46 \mathrm{Y} \cdot$ 우

* $90 / \mathrm{mm}^{3}$

\begin{tabular}{|c|c|c|c|c|c|c|}
\hline \multicolumn{4}{|c|}{ 培美後経過洔間 } & \multirow{2}{*}{$\frac{12}{4.0}$} & \multirow{2}{*}{$\frac{24}{4.5}$} & \multirow{2}{*}{$\frac{36}{4.5}$} \\
\hline 出現 & 巨核 & 球 & 数 & & & \\
\hline \multirow{4}{*}{$\begin{array}{l}\text { 運球 } \\
\text { 墐 } \\
\text { 型分 } \\
\text { 萧 } \\
\text { 核 }\end{array}$} & $\mathbf{A}$ & 型 & $\mathscr{q}$ & 25.0 & 21.1 & 21.0 \\
\hline & B & 型 & $\%$ & 12.5 & 21.1 & 15.8 \\
\hline & $\mathbf{C}$ & 型 & 96 & 21.1 & 21.1 & 10.5 \\
\hline & 合 & 計 & 96 & 58.6 & 63.2 & 47.4 \\
\hline & 成 & $2 x$ & 価 & 6.20 & 8.98 & $\gamma$ \\
\hline \multicolumn{4}{|c|}{ 好中球遊走速度 $\mu / \mathrm{min}$} & 11.37 & 9.08 & l \\
\hline
\end{tabular}

No. 6 相O $26 \mathrm{Y} \cdot \hat{o}$

* $102 / \mathrm{mm}^{3}$

\begin{tabular}{|c|c|c|c|c|c|c|}
\hline \multicolumn{4}{|c|}{ 培意後経過時間 } & 12 & 24 & 36 \\
\hline \multicolumn{4}{|c|}{ 出現巨核球数 } & 2.7 & 2.0 & 3.0 \\
\hline \multirow{4}{*}{ 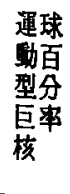 } & $\mathbf{A}$ & 型 & 96 & 25.0 & 16.6 & 25.0 \\
\hline & B & 型 & 96 & 12.5 & 16.6 & 12.5 \\
\hline & C & 型 & $\%$ & 16.6 & 16.6 & 0 \\
\hline & & 計 & $\%$ & 54.1 & 50.0 & 40.0 \\
\hline \multirow[t]{2}{*}{ 比 } & 成 & 長 & 西 & 6.76 & 10.04 & 1 \\
\hline & 毒速 & $\mu$ & in & 14.54 & 6.80 & 1 \\
\hline
\end{tabular}

No. 7 本O $26 \mathrm{Y} \cdot \hat{\delta}$

\begin{tabular}{|c|c|c|c|c|c|c|}
\hline \multicolumn{4}{|c|}{ 培释後経過時間 } & \multirow{2}{*}{$\begin{array}{l}12 \\
9.3\end{array}$} & \multirow{2}{*}{$\begin{array}{c}24 \\
14.0\end{array}$} & \multirow{2}{*}{$\begin{array}{r}36 \\
14.0\end{array}$} \\
\hline 出 現 & 巨核 & 球 & 数 & & & \\
\hline \multirow{4}{*}{$\begin{array}{l}\text { 運球 } \\
\text { 動百 } \\
\text { 型分 } \\
\text { 豆率 } \\
\text { 核 }\end{array}$} & $\mathbf{A}$ & 型 & $q$ & 10.7 & 14.5 & 10.5 \\
\hline & B & 型 & 96 & 14.5 & 14.5 & 7.1 \\
\hline & C & 型 & 96 & 21.4 & 14.5 & 0 \\
\hline & 合 & 計 & 96 & 46.6 & 43.5 & 18.6 \\
\hline 比 & 成 & 此 & 価 & 13.96 & 24.85 & \\
\hline \multicolumn{4}{|c|}{ 好中球遊走速度 $\mu / \mathrm{min}$} & 6.22 & 5.28 & \\
\hline
\end{tabular}

7 例 平均

\begin{tabular}{|c|c|c|c|c|c|c|}
\hline \multicolumn{4}{|c|}{ （7 培美後経過時間 } & 12 & 24 & 36 \\
\hline \multicolumn{4}{|c|}{ 出現巨核球 数 } & 3.9 & 5.3 & 5.7 \\
\hline \multirow{4}{*}{$\begin{array}{l}\text { 運球 } \\
\text { 動百 } \\
\text { 型分 } \\
\text { 䙵 } \\
\text { 核 }\end{array}$} & $\mathbf{A}$ & 型 & $\not 6$ & 21.9 & 20.7 & 18.5 \\
\hline & B & 型 & $\not 6$ & 15.9 & 18.5 & 12.7 \\
\hline & $\mathrm{C}$ & 型 & $\%$ & 17.5 & 10.8 & 3.4 \\
\hline & & 計 & 96 & 55.3 & 49.9 & 34.6 \\
\hline 比 & 成 & 地 & 価 & 9.05 & 14.28 & ノ \\
\hline \multicolumn{4}{|c|}{ 好中球遊走速度 $\mu / \mathrm{min}$} & 10.55 & 9.45 & 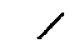 \\
\hline
\end{tabular}

で合計49.9\%が運動形態を示した．同じく36時間後 $A$ 型10.0 26.6\%, 平均18.5\%, B 型7.1 20.0\%, 平均 12.7\%, C 型 $0 \sim 10.5 \%$, 平均 3.4\%, 合計 34.6\%に運動形態が認められた。

次に組織増生を見るに，比較成長価は，培萧12時 間後5.01 13.96, 平均9.05,24時間後5.45 24.90, 平均14.28であつた．又増生帯に出現した好中球の 遊走速度は，培谱12封間後 $6.22 \sim 16.56 \mu / \mathrm{min}$, 平 均 $10.55 \mu / \mathrm{min}, 24$ 㭙間後 $5.28 \sim 13.36 \mu / \mathrm{min}$, 平 均 $9.45 \mu / \mathrm{min}$ であつた。

\section{A) 特発性栓球減少性柴斑病患者骨艏培養 の場合}

患者（男子 1 名，女子 2 名）の胸骨骨髓穿刺で得 た骨髄組織片を，健康人血清内で培養した，先ず標 本 1 枚当り増生帯に出現する巨模球数を見るに表II (No. 1) の如く，第 1 例では，培羡 12 時間後平均 5.2個，24時間後平均4.2個，36時間後平均 3.6 個之 健康人の場合とさしたる差異がなかつたが，第 2 例， 第3 例では共に健康人に比し，著しい増多を見せて いる. 即ち，第 2 例（表II. No. 2）では，培羡12時 間後平均44.6個，24時間後58.2個，36時間後58.6個 の巨核球の出現を見た．又第 3 例（表II,No.3）で は 2 回の胸骨穿刺を行なつて培娃したが，培瀁12時 


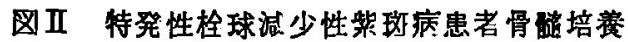

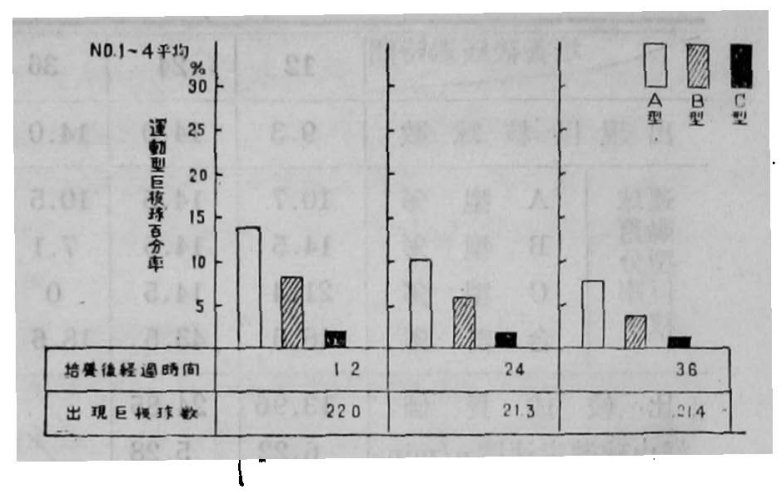

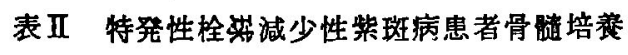

No. 1 第 1 例 松 $\bigcirc 43 \mathrm{Y}:$ ㅇ

\begin{tabular}{|c|c|c|c|c|c|c|}
\hline \multicolumn{4}{|c|}{ 培養後経過時間 } & 12 & 24 & 36 \\
\hline \multicolumn{4}{|c|}{ 出 現 巨 核 球 数 } & 5.2 & 4.2 & 3.6 \\
\hline \multirow{4}{*}{ 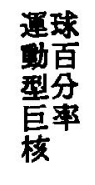 } & $\mathbf{A}$ & 型 & 96 & 15.4 & 9.5 & 3.5 \\
\hline & B & 型 & 96 & 19.2 & 4.8 & 3.5 \\
\hline & $\mathbf{c}$ & 型 & 96 & 0 & 0 & 0 \\
\hline & 合 & 計 & $\not 6$ & 34.6 & 14.3 & 7.0 \\
\hline \multirow{2}{*}{\multicolumn{4}{|c|}{$\begin{array}{c}\text { 此 较 成 長 価 } \\
\text { 好中球遊走速度 } \mu / \mathrm{min}\end{array}$}} & ノ & 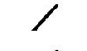 & ব \\
\hline & & & & I & ' & ' \\
\hline
\end{tabular}

No. 2 第 2 例 近 $\bigcirc 36 \mathrm{Y}:$ 우

\begin{tabular}{|c|c|c|c|c|c|c|}
\hline \multicolumn{4}{|c|}{ 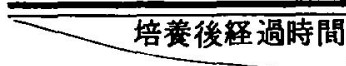 } & 12 & 24 & 36 \\
\hline \multicolumn{4}{|c|}{ 出現巨核球 数 } & 44.6 & 58.2 & 58.6 \\
\hline \multirow{4}{*}{ 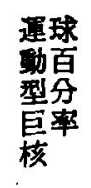 } & $\mathbf{A}$ & 型 & $\%$ & 12.1 & 8.2 & 10.2 \\
\hline & B & 型 & $\not \varnothing$ & 3.6 & 8.9 & 5.5 \\
\hline & C & 型 & $\%$ & 1.8 & 6.9 & 3.7 \\
\hline & & 計 & $\mathscr{0}$ & 17. 4 & 24.1 & 19.4 \\
\hline \multirow{2}{*}{\multicolumn{4}{|c|}{$\begin{array}{c}\text { 比 较 成 長 価 } \\
\text { 好中球遊走速度 } \mu / \mathrm{min}\end{array}$}} & / & / & l \\
\hline & & & & ノ & / & / \\
\hline
\end{tabular}

No. 3 第 3 例 坂 $\bigcirc 27 \mathrm{Y}:$ 令

\begin{tabular}{|c|c|c|c|c|c|c|}
\hline \multicolumn{4}{|c|}{ 一培羡後経過侍間 } & 12 & 24 & 36 \\
\hline \multicolumn{4}{|c|}{ 出現巨核 球 数 } & 28.3 & 24.0 & 24.0 \\
\hline \multirow{4}{*}{ 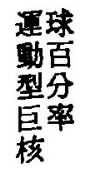 } & $\mathbf{A}$ & 型 & $\not 6$ & 12.9 & 11.1 & 8.3 \\
\hline & B & 型 & $\not 6$ & 2.4 & 5.6 & 4.2 \\
\hline & C & 型 & 96 & 0 & 4.2 & 1.4 \\
\hline & 合 & 計 & $\%$ & 15.3 & 20.8 & 13.4 \\
\hline \multirow{2}{*}{\multicolumn{4}{|c|}{$\begin{array}{c}\text { 此 较 成 長 価 } \\
\text { 好中球避走速度 } \mu / \mathrm{min}\end{array}$}} & 12.65 & 21.75 & 1 \\
\hline & & & & 10.53 & 9.87 & I \\
\hline
\end{tabular}

No. 4 第 3 例 坂 $027 \mathrm{Y} \cdot$ 令

\begin{tabular}{|c|c|c|c|c|c|c|}
\hline \multicolumn{4}{|c|}{ 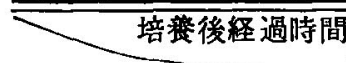 } & 12 & 24 & 36 \\
\hline \multicolumn{4}{|c|}{ 出現巨 核 球 数 } & 26.5 & 14.7 & 14.7 \\
\hline \multirow{4}{*}{ 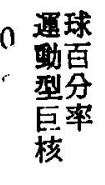 } & $\mathbf{A}$ & 型 & 95 & 15.2 & 11.4 & 8.5 \\
\hline & & 型 & $\mathscr{\%}$ & 7.6 & 4.5 & 5.7 \\
\hline & $\mathbf{C}$ & 型 & 96 & 5.7 & 0 & 0 \\
\hline & & 計 & $\mathscr{6}$ & 28.5 & 15.9 & 14.2 \\
\hline \multirow{2}{*}{\multicolumn{4}{|c|}{$\begin{array}{l}\text { 比 较 成 長 価 } \\
\text { 好中球遊走速度 } \mu / \mathrm{min}\end{array}$}} & 16.16 & 24.03 & / \\
\hline & & & & 15.95 & 10.41 & 1 \\
\hline
\end{tabular}

3 例平均

\begin{tabular}{|c|c|c|c|c|c|c|}
\hline \multicolumn{4}{|c|}{ 人培養後経過時間 } & 12 & 24 & 36 \\
\hline \multicolumn{4}{|c|}{ 出現巨核 球 数 } & 22.0 & 21.3 & 21.4 \\
\hline \multirow{4}{*}{$\begin{array}{l}\text { 運球 } \\
\text { 㠭夏 } \\
\text { 型率 } \\
\text { 核 }\end{array}$} & A & 型 & \% & 13.9 & 10.1 & 7.6 \\
\hline & B & 型 & 96 & 8.2 & 5.9 & 3.8 \\
\hline & C & 型 & 96 & 1.9 & 1.8 & 1.3 \\
\hline & 合 & 計 & $\%$ & 23.9 & 17.8 & 13.6 \\
\hline \multirow{2}{*}{\multicolumn{4}{|c|}{$\begin{array}{c}\text { 比 較 成 長 価 } \\
\text { 好中球遊走速度 } \mu / \mathrm{min}\end{array}$}} & 14.41 & 22.89 & ' \\
\hline & & & & 13. 24 & 10.14 & I \\
\hline
\end{tabular}

間後第 1 回目平均 26.5 個，第 2 回目平均 28.3 個，同 し 224 時間後第 1 回目平均 14.7 個, 第 2 回目平均 11.1 個，36時間後，第 1 回目平均14.7個，第 2 回目 平均24.0個であつた。

巨核球機能として，その運動形態を示するのを見 れば図II，表II（No.1〜4）の如くである. 即ち3 例 4 回の骨髄培羡の成績を綜合すると，培憼12時間 後 A 型12.1 15.4\%, 平均 13.9\%，B型 2.4 19.2 $\%$, 平均 $8.2 \%, \mathrm{C}$ 型 $0 \sim 5.7 \%$ ，平均 $1.9 \%$ ，合計 平均23.9\%，の巨核球が運動形悠を示すに過ぎす， 培㭥24時間後では， $A$ 型8.2 11.4\%，平均10.1\%， B 型4.5 8.9\%, 平均5.9\%, C 型0 6.9\%, 平均 1.8\%，合計 $17.8 \% ， 36$ 時間後 A 型3.5 10.2\%，平 均 7.6\%, B 型 3.5 5.7\%, 平均 3.8\%, C型 0 $3.7 \%$ ，平均 $1.3 \%$ ，合計13.6\%となり，趾康人の場 合と比较して著しくその機能の減弱している事を示 した.

一方組織増生面稫を見るに，培繁12時間後に於け る比较成長価は，平均 14.41，24時間後では，平均 22.89 であつた，又好中球遊走速度は夫ょ平均

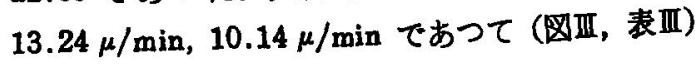
健康人の場合と殆んど有癿の差を認めなかつた。 
因正特発性栓球減少性紫斑病患者血清添加培羡

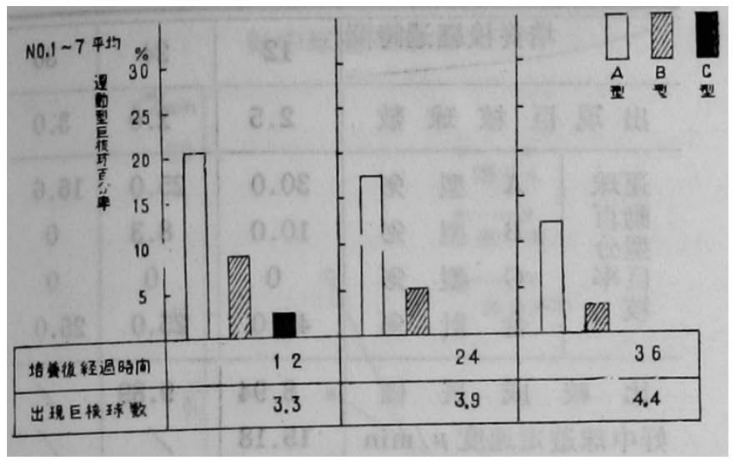

C）特発性栓球隇少性紫玨病患者血清添加 培羕の場合

患者血清中の催拴球減少性因子の有無を追求する 目的で，健康人胸骨穿刺で得た骨髓組織片を患者血 清内て培養した。

実験は第 1 例患者血清で 2 回，第 2 例で 2 回，第 3 测飞 3 回と計 7 回行なつた.

第 1 例（表III. No. 1, 2)

標本 1 枚当りの出現巨校球数は，培養12特間後 3.8 5.6個，平均4.4個， 24 時間後 4.3 4.4個，平 均4.4個，36時間後4.4〜5.2個，平均4.8個てあつた。 出現巨核球のうち，運動形態を示すすのは，培羔12

表III 特発性栓球減少性紫斑病患者血清添加培爰 第1例 No. 1 浅O 32Y · 患者: 松O 早

\begin{tabular}{|c|c|c|c|c|c|c|}
\hline \multicolumn{4}{|c|}{ (培誉後释過時間 } & 12 & 24 & 36 \\
\hline \multicolumn{4}{|c|}{ 出現巨核 球 数 } & 5.0 & 4.4 & 4.4 \\
\hline \multirow{4}{*}{$\begin{array}{l}\text { 軍球 } \\
\text { 型香 } \\
\text { 卧率 } \\
\text { 核 }\end{array}$} & $\mathbf{A}$ & 型 & 96 & 20.0 & 9.1 & 0 \\
\hline & & 型 & 96 & 0 & 0 & 0 \\
\hline & & 型 & $\%$ & 0 & 0 & 0 \\
\hline & & 計 & 96 & 20.0 & 9.1 & 0 \\
\hline \multicolumn{4}{|c|}{$\begin{array}{c}\text { 比 较 成 長 価 } \\
\text { 好中球遊走速度 } \mu / \mathrm{min}\end{array}$} & 1 & l & $\begin{array}{l}\gamma \\
\gamma\end{array}$ \\
\hline
\end{tabular}

No. 2 西 $\bigcirc \quad 38 \mathrm{Y}$ : 。

\begin{tabular}{|c|c|c|c|c|c|c|}
\hline \multicolumn{4}{|c|}{ 培美後経過時間 } & 12 & 24 & 36 \\
\hline \multicolumn{4}{|c|}{ 出現巨核球 数 } & 3.8 & 4.3 & 5.2 \\
\hline \multirow{4}{*}{$\begin{array}{l}\text { 連球 } \\
\text { 䅛面 } \\
\text { 第 } \\
\text { 核 }\end{array}$} & $\mathbf{A}$ & & $\mathscr{8}$ & 20.0 & 17.6 & 14.3 \\
\hline & B & 型 & $\not 6$ & 6.7 & 5.9 & 0 \\
\hline & C & 型 & $\not 6$ & 0 & 0 & 0 \\
\hline & & 計 & 96 & 26.7 & 23.5 & 14.3 \\
\hline \multirow{2}{*}{\multicolumn{4}{|c|}{$\begin{array}{c}\text { 比校成 長 価 } \\
\text { 好中球遊走速度 } \mu / \mathrm{min}\end{array}$}} & 7.68 & 13.40 & 1 \\
\hline & & & & & 1 & $\gamma$ \\
\hline
\end{tabular}

$\S$ 第 1 例 (No. 1.2. 平均)

\begin{tabular}{|c|c|c|c|c|c|c|}
\hline \multicolumn{4}{|c|}{ 二 培美後経過時間 } & 12 & 24 & 36 \\
\hline \multicolumn{4}{|c|}{ 出現巨核 球 数 } & 4.4 & 4.4 & 4.8 \\
\hline \multirow{4}{*}{$\begin{array}{l}\text { 運球 } \\
\text { 動百 } \\
\text { 型萃 } \\
\text { 核 }\end{array}$} & $\mathbf{A}$ & 型 & 96 & 20.0 & 13.4 & 7.2 \\
\hline & B & 型 & 96 & 3.4 & 2.9 & 0 \\
\hline & $\mathbf{C}$ & & 9 & 0 & 0 & 0 \\
\hline & 合 & 計 & 96 & 23.4 & 16.3 & 7.2 \\
\hline 比 & 成 & 長 & 価 & 7.68 & 13.40 & $/$ \\
\hline 好中球 & 走速 & 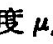 & in & ノ & 1 & 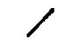 \\
\hline
\end{tabular}

時間後 $\mathrm{A}$ 型平均 20.0\%， B 型平均 3.4\%， $\mathrm{C}$ 型 0 ， 合計23.4\%であつた，培養24時間後 $\mathrm{A}$ 型平均13.4\%， $\mathrm{B}$ 型平均2.9\%, $\mathrm{C}$ 型 0 , 合計 $16.3 \%, 36$ 時間後に は，僅かにA型7.2\%の出現を見たのみで， B，C 型 巨校球は出現しなかつた。比較成長価は，培疼12時 間後7.68,24時間時13.40であつた。

第 2 例（表III. No. 3 4)

標本 1 枚当りの出現巨核球数は，培羕12時間後 2.3 5.2 個, 平均3.8個, 24時間後 2.6 4.2個, 平 均3.4個，36時間後2.5 4.2個，平均3.4個てあつた。 その内運動形態を示すすのは，培養12時間後 $\mathrm{A}$ 型平 均21.9\%, B 型平均 14.9\%， C 型平均 5.6\% 合計

§第 2 例 No. 3 凧O $27 \mathrm{Y} \cdot \delta$ 患者 近O 우

\begin{tabular}{|c|c|c|c|c|c|c|}
\hline \multicolumn{4}{|c|}{ ( 培美後経過時間 } & \multirow{2}{*}{$\frac{12}{2.3}$} & \multirow{2}{*}{$\begin{array}{l}24 \\
2.6\end{array}$} & \multirow{2}{*}{$\frac{36}{2.5}$} \\
\hline 出 現 & E 杉 & 球 & 数 & & & \\
\hline \multirow{4}{*}{$\begin{array}{l}\text { 運球 } \\
\text { 動百 } \\
\text { 型分 } \\
\text { 核 }\end{array}$} & $\mathbf{A}$ & 型 & 96 & 28.5 & 7.7 & 6.6 \\
\hline & & 型 & $\mathscr{0}$ & 14.5 & 0 & 0 \\
\hline & C & 型 & $\%$ & 7.3 & 0 & 0 \\
\hline & & 計 & 96 & 50.0 & 7.7 & 6.6 \\
\hline $\begin{array}{c}\text { 比 } \\
\text { 好中玨 }\end{array}$ & 成 & 長 & 西 & I & r & I \\
\hline
\end{tabular}

No. 4 山O $30 \mathrm{Y} \cdot \hat{\delta}$

\begin{tabular}{|c|c|c|c|c|c|c|}
\hline \multicolumn{4}{|c|}{ 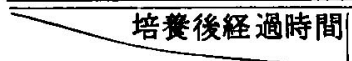 } & \multirow{2}{*}{$\frac{12}{5.2}$} & \multirow{2}{*}{$\frac{24}{4.2}$} & \multirow{2}{*}{$\begin{array}{r}36 \\
4.2\end{array}$} \\
\hline 出 琪 & 核 & 球 & 数 & & & \\
\hline \multirow{4}{*}{$\begin{array}{l}\text { 運球 } \\
\text { 動帛 } \\
\text { 型忽 } \\
\text { E率 } \\
\text { 核 }\end{array}$} & $\mathbf{A}$ & 型 & 96 & 15.3 & 14.3 & 9.5 \\
\hline & & 型 & 96 & 15.3 & 9.5 & 4.8 \\
\hline & $\mathbf{C}$ & 型 & $\mathscr{6}$ & 3.8 & 0 & 0 \\
\hline & & 計 & 96 & 34.6 & 23.9 & 14.3 \\
\hline 比 & 成 & 言 & 㑋 & 5.38 & 8.44 & 8 \\
\hline \multicolumn{4}{|c|}{ 好中球遊走速度 $\mu / \mathrm{min}$} & 18.38 & 8.85 & 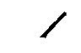 \\
\hline
\end{tabular}


$\S$ 第 2 例 (No. 3.4. 平均)

\begin{tabular}{|c|c|c|c|c|c|c|}
\hline \multicolumn{4}{|c|}{ 培羡後経過時間 } & 12 & 24 & 36 \\
\hline \multicolumn{4}{|c|}{ 出現巨核球数 } & 3.8 & 3.4 & 3.4 \\
\hline \multirow{4}{*}{$\begin{array}{l}\text { 運球 } \\
\text { 動百 } \\
\text { 型分 } \\
\text { 萧 } \\
\text { 核 }\end{array}$} & $\mathbf{A}$ & 型 & 96 & 21.9 & 11.0 & 7.6 \\
\hline & $\mathbf{B}$ & 型 & 96 & 14.9 & 4.8 & 2.4 \\
\hline & $\mathbf{C}$ & 型 & 9 & 5.6 & 0 & 0 \\
\hline & & 計 & \% & 42.3 & 15.8 & 10.5 \\
\hline \multirow{2}{*}{\multicolumn{4}{|c|}{$\begin{array}{l}\text { 比较 成 長 価 } \\
\text { 好中球遊走速度 } \mu / \mathrm{m}\end{array}$}} & 5.38 & 8.44 & $\gamma$ \\
\hline & & & & 18.38 & 8.85 & 1 \\
\hline
\end{tabular}

42.3\%を示した，24時間㣪では，A型平均11.0\%， B型平均 4.8\%, C 型 0, 合計 $15.8 \%$ 之運動形態を 示すすのが急減し，巨核球自体にす，胞体の膨化， 光輝性顆粒，空泡の出現，胞体縁の鈮菌状化，核の 浱綰等の変性像が著明に観察された，更に培美後36 時間目に至れげ， $\mathrm{A}$ 型平均7.6\%， B 型平均 2.4\%， C 型 0，合計10.5\%の巨核球が運動形態を示すに過 ぎなかつた．前記変性像も亦一層著明となつた，比 較成長価は，培養12時間後5.38，24時間後8.44であ り，好中球遊走速度は各時間後，夫々 $18.38 \mu / \mathrm{min}$, $8.85 \mu / \mathrm{min}$ であつた.

第 3 例（表亚. No. 5 7）標本 1 枚当りの出現巨 核球数は，培養12時間後2.2 2.3個，平均 2.3 個，

§第 3 例 No. 5 井O 28Y : 今 患者: 坂○ 今

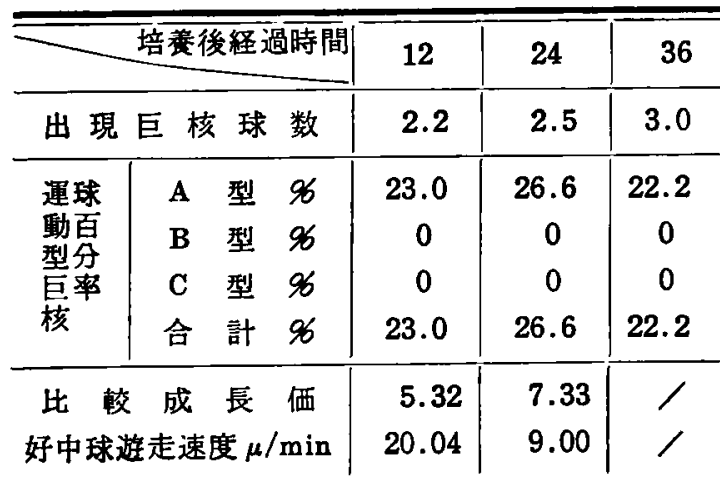

No. 6 平 $\bigcirc 46 \mathrm{Y}:$ ㅇ

\begin{tabular}{|c|c|c|c|c|c|c|}
\hline \multicolumn{4}{|c|}{ 二 培羡後経過時間 } & 12 & 24 & 36 \\
\hline \multicolumn{4}{|c|}{ 出現巨核 球 数 } & 2.2 & 3.4 & 4.2 \\
\hline \multirow{4}{*}{$\begin{array}{l}\text { 運球 } \\
\text { 動百 } \\
\text { 型分 } \\
\text { 巨率 } \\
\text { 核 }\end{array}$} & $\mathbf{A}$ & 型 & 96 & 9.1 & 23.5 & 16.6 \\
\hline & B & 型 & $\not 6$ & 18.2 & 11.7 & 11.1 \\
\hline & C & 型 & 96 & 8.2 & 0 & 0 \\
\hline & 合 & 計 & 96 & 35.5 & 35.3 & 27.7 \\
\hline 比阵 & 成 & 長 & 価 & 6.35 & 8.95 & I \\
\hline \multicolumn{4}{|c|}{ 好中球避走速度 $\mu / \mathrm{min}$} & 12.38 & 7.14 & $\gamma$ \\
\hline
\end{tabular}

No. 7 相O 26Y : 令

\begin{tabular}{|c|c|c|c|c|c|c|}
\hline \multicolumn{4}{|c|}{ (培盖後経過時間 } & \multirow{2}{*}{$\frac{12}{2.5}$} & \multirow{2}{*}{$\frac{24}{2.0}$} & \multirow{2}{*}{$\frac{36}{3.0}$} \\
\hline 出 現 & 巨核 & 球 & 数 & & & \\
\hline \multirow{4}{*}{$\begin{array}{l}\text { 運球 } \\
\text { 動百 } \\
\text { 型分 } \\
\text { 核 }\end{array}$} & $\mathbf{A}$ & 型 & $\not 6$ & 30.0 & 25.0 & 16.6 \\
\hline & B & 型 & 96 & 10.0 & 8.3 & 0 \\
\hline & C & 型 & 96 & 0 & 0 & 0 \\
\hline & & 計 & 9 & 40.0 & 25.0 & 25.0 \\
\hline 比 & 成 & 地 & 伍 & 8.94 & 9.89 & ノ \\
\hline 好中球 & ：走速 & $\neq$ & $\min$ & 15.18 & 1 & $\gamma$ \\
\hline
\end{tabular}

$\S$ 第 3 例 (No. 5,6,7 平均)

\begin{tabular}{|c|c|c|c|c|c|c|}
\hline \multicolumn{4}{|c|}{ 培養後経過時間 } & \multirow{2}{*}{$\frac{12}{2.3}$} & \multirow{2}{*}{$\frac{24}{2.6}$} & \multirow{2}{*}{$\frac{36}{3.4}$} \\
\hline 出 現 & 巨格 & 球 & 数 & & & \\
\hline \multirow{4}{*}{$\begin{array}{l}\text { 運球 } \\
\text { 動百 } \\
\text { 型分 } \\
\text { 率 } \\
\text { 核 }\end{array}$} & $\mathbf{A}$ & 型 & $\not 6$ & 20.7 & 25.0 & 18.5 \\
\hline & B & 型 & 96 & 9.4 & 6.7 & 3.7 \\
\hline & $\mathbf{C}$ & 型 & $\not 6$ & 2.7 & 0 & 0 \\
\hline & & 計 & ğ & 32.8 & 31.7 & 22.2 \\
\hline 比車 & 成 & Ix & 価 & 7.20 & 8.71 & / \\
\hline \multicolumn{4}{|c|}{ 好中球遊走速度 $\mu / \mathrm{min}$} & 15.87 & 8.07 & ノ \\
\hline
\end{tabular}

No. $1 \sim$ No. 7 平均

\begin{tabular}{|c|c|c|c|c|c|c|}
\hline \multicolumn{4}{|c|}{ 培食後経過㭙間 } & 12 & 24 & 36 \\
\hline \multicolumn{4}{|c|}{ 出現巨核球数 } & 3.3 & 3.3 & 3.8 \\
\hline \multirow{4}{*}{$\begin{array}{l}\text { 運球 } \\
\text { 動百 } \\
\text { 型分 } \\
\text { 萃 } \\
\text { 核 }\end{array}$} & $\mathbf{A}$ & 型 & 96 & 20.8 & 17.7 & 12.3 \\
\hline & $\mathbf{B}$ & 型 & 96 & 9.2 & 5.1 & 3.4 \\
\hline & C & 型 & $\%$ & 2.8 & 0 & 0 \\
\hline & & 計 & 96 & 32.8 & 22.8 & 15.7 \\
\hline 比 較 & 成 & 理 & 価 & 6.73 & 9.60 & 1 \\
\hline 好中球入 & 走速 & $\mu$ & $\min$ & 16.49 & 8.33 & / \\
\hline
\end{tabular}

24封間後2.0 3.4個，平均2.6個，36時間後3.0 4.2個，平均3.4個であつた，その内運動形態を示す あのは 12 時間後 $\mathrm{A}$ 型平均 $20.7 \%, \mathrm{~B}$ 型平均 $9.4 \%$, $\mathrm{C}$ 型平均 $2.7 \%$, 合計 $32.8 \%$ であつたが, 24時間後 には， $\mathrm{A}$ 型平均25.0\%，B型平均 6.7\%， C 型 0 , 合計 $31.7 \%$ となり，36特間後には，A 型平均 $18.5 \%$, $\mathrm{B}$ 型平均 $3.7 \%, \mathrm{C}$ 型 0 , 合計 $22.2 \%$ であつた。 一 方比较成長価は，12時間後 $7.20 ， 24$ 時間後8.71であ り，好中球遊走速度は，12㭙間後 $15.87 \mu / \mathrm{min} ， 24$ 㭙間後 $8.07 \mu / \mathrm{min}$ であつた。

以上 3 例の患者血清添加培羡の場合の平均值を

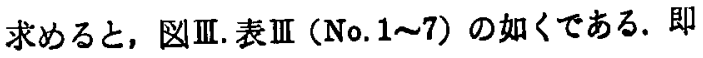


因IV 好中球遊走速度並びそ比較成長価 好中球遊走速度

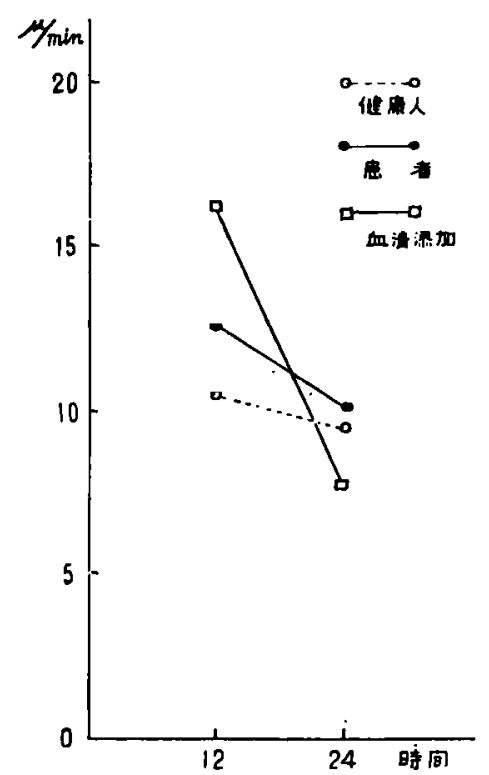

比较成 長 価

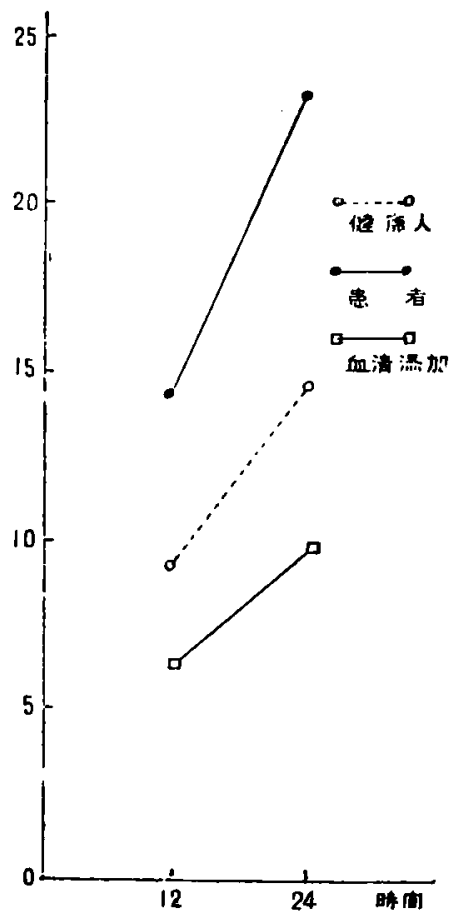

ち，巨.校球の出現個数は，培盖 12 特間後 $2.2 \sim 5.2$, 平均3.3個，24時間後2.0 4.4，平均3.3個，36時間 後2.5 5.2平均3.8個である．その運動形態を胃る と，12㭙間後 A 型 9.1 30.0\%，平均 $20.8 \%$ ，B型 $0 \sim 18.2 \%$, 平均 $9.2 \%, \mathrm{C}$ 型 $0 \sim 8.2 \%$, 平均 2.8 \%, 合計32.8\%であつた. 24 時間後では，A 型9.1 $\sim 26.6 \%$, 平均 $17.7 \%$, B型 $0 \sim 11.7 \%$, 平均5.1
$\%$ ， C 型 0, 合計22.8\%，36時間後ではA 型平均 12.3\%，B型平均3.4\%， C 型 0, 合計15.7\%が運 動形態を有する巨核球として観察された。增生の比 較成長価は，12時間後平均 $6.73 ， 24$ 時間後平均 9.60 , 好中球遊走速度は，夫々，16.49 $\mu / \mathrm{min}, 8.33 \mu / \mathrm{min}$ であつた（表III. No.1〜7, 図IV).

\section{第4章 総括並ひに考按}

1915年 Frank2) は，本症が，流血中の栓球减少 を主徴とする所から，之をDie Essentielle Thrombopenie と命名した。以後その栓球減少の成因に関 して, 種々の研究，推論がなされて来た．即ち Frank は，その成因を，脾より産生されたある種 の因子による骨艏巨核球の栓球形成障碍に由来する あのとした. Wright 以来，拴球が巨核球より産生 される事が結論されている以上当然の事といえよう. 1916年 Kaznelson3) は，本症慢性型に脾腫のある 事，剔脾によつて，栓球数の増多，出血性素因の軽 減を来す事実を見出し，剔出脾の塗沫標本中に，栓 球及び，その母細胞である目核球の存在を観察し， 本症朝に於ける栓球抑留乃至破壊作用の穴進が，栓 球减少を来すと主張した. Doan ${ }^{19)}$ (1940) は，之を 支持し，脾内の栓球貪喰作用の六進を認め，Bell20) （1935）す之を鹤流実験により確認した，次に脾内 に，ある種の物質が過剩に生産され，その結果巨核 球㙨能が障碍される為，流血中の栓球減少を来すと 主張する者がある，即ち，Frank は，本症に於ける 栓球減少は，脾が，巨核球に中毒性退行変性を来さ しめる為と考えたが，この説は，Limarzi \& Schlei-

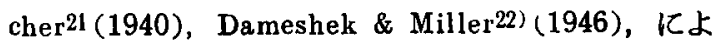

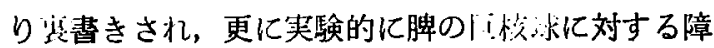
碍作用を証明せんとして Torrioli23)(1938)，Troland \& Lee24) (1938) 亿始まり, Hobson25) (1940) Harrington et al26)(1951), 奥田27)(1952), 平岡28) （1953），角南・粟井29)（1956）等の報告があり，何 れも巨核域に対する脾の障码作用因子のある事を証 明している，以上の如く，本症成因関して，この 脾性因子の存在む看過する事の出来ない重要な一因 于と考えられる。最近 Stefanini \& Dameshek 30 ) （1953）等は本䇥慢性型で，剔聘無效例を経験し， 且つ患者血清中の栓球疑集性因子を证鹏した事から， 本症の成因を免疫学的㙨枟加説明せんとしている. 又食䬣性アレルギーを本症成因とする Madison (1937)，副督皮質ホルモン，性ホルモンの流血中栓 球放，毛細血管の抵抗性との関係を举ける Lozner 
(1951) 森田32)（1952）等がある.一方本症に於い ては，栓球減少と同時に，毛細血管脆弱性のある 所加ら，之を本症成因の第1亿挙ける Bedson60)

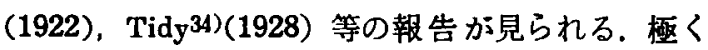
最近では. ACTH, や Cortison が本症患者の治療 面に於いて，著効を収める事より，本症成因を，免 度学的機忶によると主張する説もある(4)-10).

さて，従来より，本症患者の体液乃至血液内に催 栓球減少性因子の存在する事を主張するあのが多い， 即ち, 古くは，本邦平井35)36）（1919）は，本症患者 血液又は，血清を海狽腹腔内に注射して，腹部满器 に出血を惹起せしめ，同時に栓球减少の起る事実を 認めた. 最近では，Harringion et al26)(1951) に よれば，本症患者の全血及び血等を健康人に注射し て，その栓球が著減し，しかあ 1 回の注射で数日間 もその状態の持続する事を見ており，KissmyerNielsen ${ }^{37}$ （1953）も同様の実鈳成績を報告した．又 Stefanini38) 等 (1952) は，多血症患者の栓球加本 症患者体内での生存期間の短汃事を観察して, 催 栓球减少性因子が，本症患者流血中に存在するもの と推論している，Hirsh40)(1951）等も，本症の急性 型では栓球破壊, 慢性型では，栓球産生抑制の因子 が体液内に存在すると考えた. 又, 本邦友田, 平岡 等39（1957）は，本症患者の剔脾前仼証明された血 清中の催栓球减少性因子が, 剔脾後は証明されなか つた事から，本症成因を脾条件反応の立場加ら説明 せんとしている，石上，阿部41）(1951）は，本症患 者骨檤血中に，巨核球の栓球産生能を障碍し，乃至 は，栓球破壊を起す物質の存在する事を試験管内実 験で証明し，三骗，奧田等42）(1952）は，本症患者 血清を家兔注射する事によつて，血清中に催栓球 減少性因子の存在する事を証明し，しか6同血清中 の催貧血性物質と異喠のものである事を確認し，森 田32）(1952）も同様の経験を報告し，患者血整中の 催栓球減少性物澌の存在と同時に, 巨栈球の栓球産 生障㥂のある事を指摘している，教室粟井は家兔骨 祖灌流実験により，本症患者血清中の催栓球減少性 因子の存在を確恋している. 斯くの如く，本症患者 血清中乃至血液中の催栓球減少性因子の存在を主張 するあのは，数多くある.

栓球の巨核球より分離される事実は，今日何人之 いえども，之を疑う者はなく，従つて，本症の主徽 である栓球減少を淪ずるに当つては，巨核球の機能 に言及せ枋ばならない，本症に於ける巨校球の形態 学的研究は，Frank が初めてこの異常なる事を報
告して以来，その栓球生成像の漍少と成羖障碍を認 める Rohr44) (1934), Heilmyer45) (1951), Dameshek \& Miller 22) (1946), Pisciotta, Stefanini \& Dameskek46)（1953）等や, 栓球生成像の堿少のみ を主張する Willi47) (1935), Lawrence \& Knutti48) (1934)，Fuente49) (1949)，及び巨核球に変化なし とする Minot50) (1917), Markoff (1938) 等の多く の報告がある．しかし乍ら，之等の多くは，組蟣切 片乃至垒沫染色標本による静態観察よりの推測の域 を脱せず，動態観察は余り行なわれていない，最近 に到り, Stefanini, Dameshek 等51)(1952)の位 相差顕徽鏡による超生体観察, 滝川の超生体染 色による栓球分離像の観察が行なわれる様にな つたが，細胞の新鮮度，長時間任亘る観察という面 に於いて尚完全なむのとは言い難かつた，当教室で は, 近年骨䯣の体外組穖培羡化成功し, 従来不可能 であつた骨稙内諸細胞の動態観察が可能となつた. 就中巨核球の動態観察では数々の新知見が発表され て来た. 角南・粟井29552（1956）は，本症患者骨䯣 を培垠して，巨核球嘰能を観察し，健康人のそれと 比較した，即ち，健康人巨核球は，培養12 24時間 目頃增生帯に最も多く出現し, その数は, 普通 1 5 ケ平均 2.4 個であり，成就巨核球の内，俑足運動 を示すむのは少なくとも30\%，時には80\%に達する. 然るに人の慢性型の特発性栓球減少性紫病の骨䯣 では，增生帯に出現する巨核球数は，健康人の比し て增多を示すすのが多く，その内運動形態をとるも のは 0 5.996亿過ぎないという. 巨核球の大多数 は運動形態を示さず，鮮鋭な境界を有する正円形に 近い細胞として認められ，僅加変形運動を見るの みであつたと述へている，更にての方法によつて， 患者脾抽出液の添加が，巨核球の機能を低下せしめ る事をも確認している.

私は教室考案になる簡易組織培養法を用いて，患 者血清中の催恮球減少性因子を証明せんと試み，健 应人巨核球の栓球産生の状態を動態観察すると共に, 趾冰人指随を患者血清中で培養し，その巨核球機能 の変化を追求した。

健康人骨髄を健康人血清中で培義した場合，増生 帯に出現する巨.核球数は，培養12時間後，平均 3.9 個, 24㭙間後5.3個，36時間後5.7個であり，その内 運動形態を示すものは，12時間後平均55.3\%，24㭙 間後49.9\%，36特間後34.6\%であつた. 之等の值は， 己に報告された角南・粟井の，海野式グラスを用い た時の值とほほ同值乃至は高値を示している，海野 
式グラスによる時は，載物グラスと，カバーグラス の間隔が $900 \mu$ あり, 細胞增生帯が䅕密な為, 間 隔が $600 \mu$ で堌生帯の薄い簡易培養法に比して, 巨核球が，他の細胞に掩われる事が多かつた為であ ろう.一方組織増生の比較成長価は，12時間後平均 9.05,24時䦐後14.28であり，好中球遊走速度は12時 間後 $10.55 \mu / \mathrm{min}, 24$ 時間後 $9.45 \mu / \mathrm{min}$ であつて， 已に小野53）(1956）か，簡易培羡法によつて得た值 とほほ同値乃至稍々高値を示している。

本症患者骨髄を簡易培養法で培養した場合を見る と，出現する巨核球数は，第 1 例では健康人の場合 之差異がなかつたが，第 2 ，第 3 例では，何れむそ の数を増しているのが注目される．従来の諸家の報 告には，本症患者の巨核球は一般に増加するとする ものが多いが，私の場合も 1 例は正常，2 例は増加 した，一方その運動形笂を見ると，出現個数の多少 に不拘，著しくその機能の低下を思わせる．即ち培 羡12,24,36時間後に23.9\%，17.8\%，13.6\%が運動 形笪を示すに過ぎず就中触手状突起又は，偽足形成 巨核球の著明な減少が目立ち，乙の事は前述の角 南・粟井の実験とよく一致している，又比較成長価， 好中球遊走速度に関しては健康人の場合之有意の差 が認められなかつた。

3 例の患者の血清を用いて, 都合 7 回健康人骨䯣 を培養した場合，増生帯に出現する巨核球数は，培 羡12時間後 7 回を平均して3.3個，24時間後3.3個， 36時間後3.8個であつて, 健康人血清中での培養の 場合と，有意の差がなつた，然るに出現巨㧼球の 内，運動形態を示すすのを見ると，各例を平均して， 培養12時間後 $\mathrm{A}$ 型20.8\%，B 型9.2\%， C 型2.8\%， 合計32.8\%であり，健康人血清中培悂の際の合計 55.3\%に比し低值を示した. 24時間後，A 型17.7\%， B 型5.1\%， C 型 0，合計 22.8\%であつたが，健康 人血清中培養の際に比すればその1/2にも満たない. 更に36㭙間後になると，巨核球機能の低下は尚一層 著明で，A 型 12.3\%， B 型 3.4\%， C 型 0，合計 15.7\%に過ぎず，健康人血清中培養の際の34.6\%を， 遥汃下迴る值を示した，又同時に紏胞自体の変性 像も著明に見られた，組織増生の比較成長洒の平均 值は，12時間後7.23，24時間後10.55，好中球遊走速

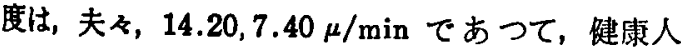
血清中培关の場合とほとんど有意の差を認める事が 出来なかつた。

跟康人骨髄を，健康人血清内で培羑すれば，栓球 産生能の最も旺盛な触手状突起形成巨核球の他, 偽
足形成，胞体変形などの運動形態をとる巨核球が増 生帯に現われ，且つ培羑後の時間の経過と共にその 数を減ずる，しかしその程度は，余り急激ではない。 巨核球自体の変性像も培羡24時間目頃まででは，ほ とんど見られない，然るに，患者血清中で培溔すれ ば，出現巨核球数に差異なきに不拘，その触手状突 起形成巨核球が著しく減少し，更に偽足形成巨核球 屯减少し，僅汃に，胞体変形巨核球のみか;，対照標 本群と同程度に出現するに過ぎない，しかあ斯かる 巨核球機能の低下は，培養後の時間の経過と共に， ますますその程度を強めて来る，更に，巨核球自体 の変性像む，培養後比較的早期より観察される. 又 一方，比較成長価，好中球遊走速度に関しては，硉 康人血清中，患者血清中を問わず余り差異が見られ ない.

之等の事実は，本症患者の巨核球の塗沫染色標本， 乃至位相差顕微鏡による従来の研究に基く巨核球の 退行変性, 成熟障碍, 栓球生成像の减少像等の主張 と考え合わせて興味深いものがある．從来の方法に よる上記の如き巨核球像の観察は，多く患者骨䯣 内に於て見られる変性乃至成熟障碍に関するもので あるが，私の実験では，健康人骨髄にも直接作用し て，健康巨核球の機能を低下せしぬ得る因子が，患 者血清中に存在する事を亳付ける事が出来た。 又か かる血清中の因子が，他の骨㖪系細胞に影響を与え ず，独り直接骨艏巨核球の栓球産生抑制，流血中栓 球の减少，出血性素因を発現せしめる重要な因子で ある事は，疑いをはさむ余地がない。

\section{第 5 章 結 論}

特発性栓球減少性紫斑病の，血清中の催栓球減少 性因子を追求する目的で，簡易骨髄組織培養法を用 いて，健康人，本症患者の骨䯣を培養し，更に本症 患者血清中で健康人骨䯣を培羡して, 夫々, 増生帯に 出現する巨核球の数，運動形態，並びに組織增生比 較成長佂，好中球遊走速度を観察した。

1）本症患者骨髓培赛では，出現巨核球は，1例 では正常，2 例では增加を示したが，その機能は著 しく低下した。比較成長価，好中球遊走速度は，対 照と有荱の差を認めなかつた。

2）硉康人骨随を，本症患者血清中で培䇅した場 合，巨校球の出現個数は，対照と有意の差がなかつ たが，その機能に著しい低下を見ると共に，著明な 変性像を認めた。比校成長価, 好中球遊走速度には, 対照亡有莣の差を認めなかつた。 
以上より，本症患者血清中には，骨䯙巨核球に直 接作用して，その栓球産生を抑制する因子の存在す る事を知つた。

擱筆するにあたり，御烈篤なる御指導と御校閲を
賜わつた恩師平木教授並びそ角南講師に深甚なる謝 意を表する。

（本論文の要旨は第20回日本血液学会総会に於、 てて発表した).

\section{Clinical and Experimental Studies on the Characteristics of Idiopathic Thrombocytopenic Purpura}

\section{Part 1. The Influence of the Serum of the Patient with Idiopathic Thrombocytopenic Purpura on the Megakaryocyte Function of Normal Persons}

By

\section{Seiken Honda}

Department of Internal Medicine Okayama University Medical School

(Director: Prof. Kiyoshi Hiraki)

With the purpose to pursue the platelet reducing factor in the serum of idiopathic thrombocytopenic purpura, the author performed the bone-marrow tissue culture of the normal persons and the patients with this disease by the simple method of bone-marrow tissue culture; and also observed number of megakaryocytes, their functions (motility and separation of platelets) in the tissue growth area, relative tissue growthrate, and the wandering velocity of neutrophils by means of the bone-marrow tissue culture of normal persons in the serum of patient with this disease.

1. In the bone-marrow tissue culture of this disease number of megakaryocytes appearing in the tissue growth area was normal in one case, and greater than the normsl in two cases; but the megakaryocyle funcion was on the whole lowered. The relative growth rate and the wandering velocity of neutrophils showed no significant differences from those of the control.

2. In the case of the bone-marrow tissue culture of normal persons in the serum of this disease there was no significant difference in the number of megakryocytes appearing in the growth area from that of the control, but the megakaryocyte function was markedly diminished and also a marked degeneration was recognized. However, the relative growth rate and the wandering velocity of neutrophils showed no significant differences from those of the control.

From these findings it is clear that there exists some factor in the serum of the patient with thrombocytopenic purpura, which acts directly on megakarycoytes so as to inhibit the thrombocyte production. 